\title{
Dengue: An Escalating Problem of Our Society
}

\author{
Faiza Naseer1", Attiya Nazish1, Rida Khan2, Samra Sadiq1, Nadia Perveen1, \\ Zainab Kaleem², Shaneel Kausar', Muhammad Zeeshan Ashraf ${ }^{1}$ \\ ${ }^{1}$ College of Pharmacy, GC University, Faisalabad, Pakistan \\ ${ }^{2}$ Department of Physiology and Pharmacology, Agriculture University, Faisalabad, Pakistan \\ Email: ${ }^{*}$ faiza.naseer@ymail.com
}

Received 19 December 2014; accepted 13 January 2015; published 20 January 2015

Copyright (C) 2015 by authors and Scientific Research Publishing Inc.

This work is licensed under the Creative Commons Attribution International License (CC BY). http://creativecommons.org/licenses/by/4.0/

(c) (i) Open Access

\begin{abstract}
Dengue virus infection is more and more acknowledged as one of the world's major escalating problems. Dengue is prevalent in most tropical and subtropical countries. To solve this problem, pharmacists need to understand the epidemiology, risk factors, clinical spectrum, diagnosis, management, prevention, and novel avenues of dengue.
\end{abstract}

\section{Keywords}

Dengue, Escalating, Pharmacist, Prevention, Novel Avenues

\section{Introduction}

Dengue is the most frequent origin of arboviral infection. Four dengue (DEN) virus serotypes are, known as DEN-1, DEN-2, DEN-3, and DEN-4. They fit into the genus Flavivirus, family unit Flaviviridae having approximately 70 viruses [1]. Now, the disease is more widespread than at any other time, and its dominance is estimated to augment. The factors are complex and not fully understood, responsible for the dramatic reappearance of epidemic dengue and dengue hemorrhagic fever (DHF), correspondingly, as a universal community health problem in the past 17 years. Though, the recurrence appears to be directly related with demographic and communal changes more than the past 50 years [2]-[5]. Two major factors have been the recorded global population growth and the associated unplanned and uncontrolled urbanization, especially in tropical developing countries. Ideal conditions for increased transmission of mosquito-borne diseases in tropical urban centers have produced by the imperfect housing, crowding, and deterioration in water, open drain, and waste management systems allied with spontaneous urbanization.

\footnotetext{
${ }^{*}$ Corresponding author.
}

How to cite this paper: Naseer, F., Nazish, A., Khan, R., Sadiq, S., Perveen, N., Kaleem, Z., Kausar, S. and Ashraf, M.Z. (2015) Dengue: An Escalating Problem of Our Society. Open Journal of Epidemiology, 5, 9-13. 
Lack of effective mosquito control is a third major factor in areas where dengue is widespread [2] [4] [5]. Space spraying with insecticides to kill adult mosquitoes has been the most emphasized factor during the past 25 years; this has not been successful [7] and, in fact, has been adverse to prevention and control efforts by giving the general public of the society and government officials a "false sense of security". Enlarged air travel is a fourth factor responsible for the global appearance of dengue and DHF, which provides the perfect mechanism for the transfer of dengue and other urban pathogens between population centers of the world [2]-[5]. Decay in public health infrastructures in most countries in the past 30 years has been considered a fifth factor that has contributed to the reappearance of pandemic dengue. A critical shortage of trained specialists who understand and can develop effective prevention and control programs for vector-borne diseases has created by lack of funds. Concurrent with this has been a revised in public health policy that positioned importance on disaster response to epidemics by using high-technology mosquito control methods rather than on preventing those epidemics by using larval source decline through ecological sanitation, the only method that has been shown to be successful [5].

In short, lack of resources for vector-borne infectious disease prevention and control, demographic and communal changes, and changes in public health policy have all contributed to amplifying happening dengue activity, the expansion of hyperendemicity, and the appearance of epidemic DHF.

Dengue hemorrhagic fever (DHF) is a critical sign of dengue, which is more frequent after a secondary infection with dengue virus. Cost effective vaccine and drugs are considered necessary for the prevention and control of dengue.

\section{Dengue Case Classification}

Alteration in the dengue epidemiology escorts to problems with the use of the presented WHO classification. Symptomatic dengue virus infections were grouped into three categories: undifferentiated fever, dengue fever (DF) and dengue hemorrhagic fever (DHF). DHF had more classified into four severity grades, with grades III and IV being defined as dengue shock syndrome (DSS) [8]. Many problems have been reported with the use of this classification [9]-[11], which were summarized in a systematic literature review [12]. Problems in applying the criteria for DHF in the clinical situation, jointly with the increase in clinically severe dengue cases which did not accomplish the strict criteria of DHF, led to the request for the classification to be reconsidered. Presently the classification into DF/DHF/DSS continues to be extensively used [9]. Suggested dengue case classification and levels of severity (Table 1) has a high potential for being of convenient use in the clinicians' decision as to where and how intensively the patient should be observed and treated, in more consistent exposure in the national and international surveillance system, and as an endpoint measure in dengue vaccine and drug trials.

\section{Diagnosis of Dengue}

For clinical care efficient and accurate diagnosis of dengue is of primary importance (i.e. Early recognition of severe cases, case authentication and differential diagnosis with other infectious diseases), surveillance actions, outbreak control, pathogenesis, academic research, vaccine development, and clinical trials.

Table 1. Suggested dengue case classification and levels of severity.

\begin{tabular}{|c|c|c|}
\hline Criteria for dengue & Warning signs & Criteria for severe dengue \\
\hline $\begin{array}{l}\text { Probable dengue } \\
\text { - } \quad \text { live in/travel to dengue endemic area. } \\
\text { - } \quad \text { Fever and } 2 \text { of the following criteria: } \\
\text { - } \quad \text { Nausea, vomiting } \\
\text { - } \quad \text { Rash } \\
\text { - } \quad \text { Aches and pains } \\
\text { - } \quad \text { Tourniquet test + ve } \\
\text { - } \quad \text { Leukopenia } \\
\text { - } \quad \text { Any warning sign }\end{array}$ & $\begin{array}{ll}\text { - } & \text { Abdominal pain or tenderness } \\
\text { - } & \text { Persistent vomiting } \\
\text { - } & \text { Clinical fluid accumulation } \\
\text { - } & \text { Mucosal bleeding } \\
\text { - } & \text { Lethargy, restlessness } \\
\text { - } & \text { Liver enlargement }>2 \mathrm{~cm} \\
\text { - } & \text { Laboratory: } \uparrow \text { in HCT } \\
\text { - } & \text { Concurrent with rapid } \downarrow \text { in platelet count }\end{array}$ & $\begin{array}{l}\text { Severe plasma leakage leading to: } \\
\text { - } \quad \text { Shock (DSS) } \\
\text { - } \quad \text { Fluid accumulation with respiratory } \\
\text { distress } \\
\text { Severe bleeding } \\
\text { As evaluated by clinician } \\
\text { Severe organ involvement } \\
\text { - } \quad \text { Liver: AST/ALT } \geq 1000 \\
\text { - } \quad \text { CNS: Impaired consciousness } \\
\text { - } \quad \text { Heart and other organs as well }\end{array}$ \\
\hline $\begin{array}{l}\text { Laboratory-confirmed dengue } \\
\text { (Important when no sign of plasma leakage) }\end{array}$ & $\begin{array}{c}\text { *(Requiring strict observation and medical } \\
\text { intervention) }\end{array}$ & \\
\hline
\end{tabular}




\section{Clinical Management and Delivery of Clinical Services}

Dengue virus causes a systemic and dynamic disease which has a wide clinical spectrum that includes both severe and non-severe clinical features [13]. The illness begins abruptly and is followed by the three phases-febrile, critical and recovery (Table 2) after the incubation period. For an infection that is complex in its manifestations, management is relatively simple, economical and very effective in saving lives so long as right and well-timed interventions are instituted. The key is early identification and understanding of the clinical troubles during the different phases of the illness, leading to a rational approach to case management and an excellent clinical result. Pharmacist should ensure stepwise approach to the clinical management of dengue given in Table 3 and Table 4.

\section{Severe Dengue}

Severe dengue is defined by one or more of the following:

1) Plasma leakage that may lead to shock (dengue shock) and/or fluid accumulation, with or without respiratory distress, and/or

2) Severe bleeding

3) Severe organ impairment

If the patient is from an area of dengue risk presenting with fever of 2 - 7 days plus any of the following manifestations severe dengue should be considered:

1) Plasma leakage supported by such as: high or progressively rising haematocrit; pleural effusions or ascites; circulatory compromise or shock (tachycardia, cold and clammy extremities, capillary refill time greater than three seconds, weak or untraceable pulse, narrow pulse pressure or, in late shock, recordable blood pressure).

2) Significant bleeding

3) Altered level of consciousness (lethargy or restlessness, coma, convulsions)

4) Severe gastrointestinal involvement (constant vomiting, growing or intense abdominal pain, jaundice

5) Severe organ destruction (acute liver failure, acute renal failure encephalopathy or encephalitis, or other unusual manifestations, cardiomyopathy) or other curious manifestations.

\section{Prevention and Control of Dengue}

For effective programmed management important activities are regular monitoring of the delivery of dengue prevention and control services and evaluation of the impact of interventions. Appropriate indicators should be

Table 2. Febrile, critical and recovery phases in dengue.

\begin{tabular}{llll}
\hline \multicolumn{2}{c}{ Febrile phase } & \multicolumn{1}{c}{ Critical phase } & \multicolumn{1}{c}{ Recovery phase } \\
\hline - Dehydration & $\bullet$ & Shock from plasma leakage & Hypervolemia (only if intravenous fluid \\
- High fever & $\bullet$ & Severe hemorrhage & therapy has been excessive and/or has \\
- Neurological disturbances & $\bullet$ & Organ impairment
\end{tabular}

Table 3. A stepwise approach to the clinical management of dengue.

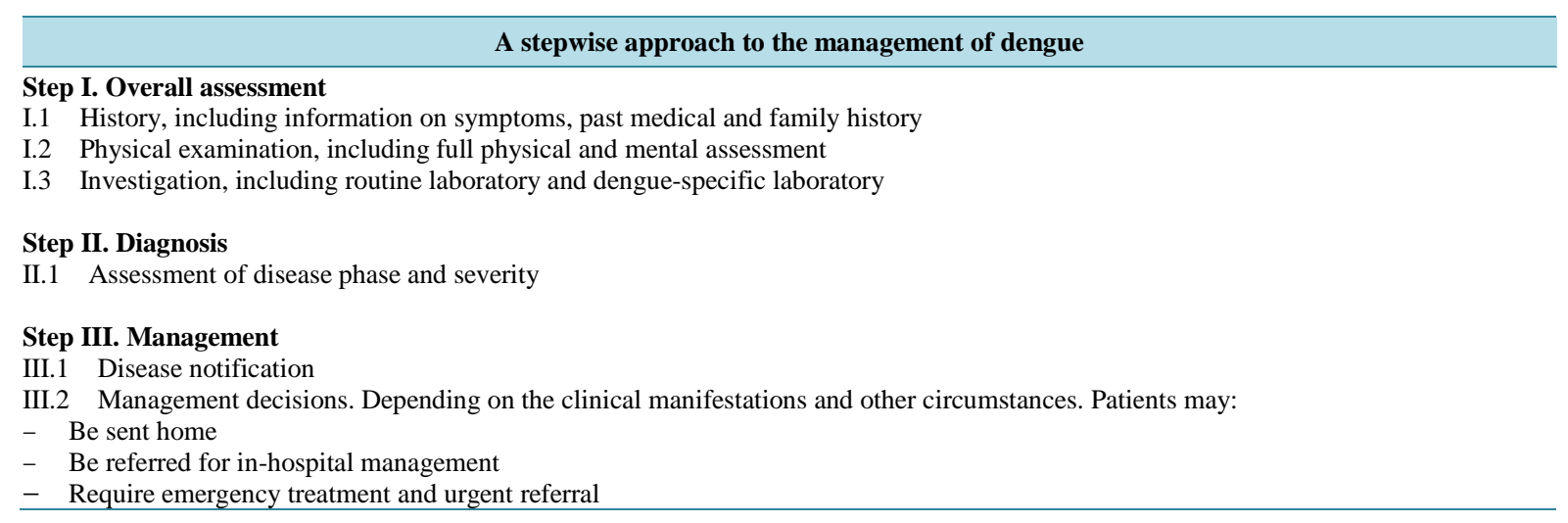


recognized to measure the advancement of execution, with output and outcome indicators.

\section{Rational Practices to Treat Dengue Patient}

The pharmacist should play a key role in good clinical practices to ensure rational treatment to the dengue patient as given in Table 5.

\section{Novel Avenues}

Vector control and personal protection from the bites of infected mosquitoes are currently possible key prevention

Table 4. Examples of good and bad practice in dengue prevention and control.

\begin{tabular}{|c|c|c|}
\hline Activity & Good practice & Bad practice \\
\hline $\begin{array}{c}\text { Environmental } \\
\text { management }\end{array}$ & $\begin{array}{l}\text { Determining local ecology of immature stages as a basis } \\
\text { for choosing the most appropriate interventions } \\
\text { Integrating dengue control with sanitation, solid waste } \\
\text { disposal, water supply services and other vector and pest } \\
\text { control programs }\end{array}$ & $\begin{array}{l}\text { Investing disproportionately in chemical control } \\
\text { methods when affordable and more sustainable } \\
\text { environmental management solutions are available. } \\
\text { Responding primarily to outbreaks and not investing in } \\
\text { sustained vector control measures. }\end{array}$ \\
\hline Chemical control & Using insecticides judiciously & $\begin{array}{l}\text { Using chemical control methods without } \\
\text { Evaluating efficacy and cost-effectiveness, and } \\
\text { Without monitoring local vector susceptibility. }\end{array}$ \\
\hline Municipal services & $\begin{array}{l}\text { Intersectoral collaboration on urban development or } \\
\text { renewal to minimize the availability of larval habitats of } \\
\text { dengue vectors and vectors of other diseases }\end{array}$ & $\begin{array}{l}\text { Social marketing of larvicides for water-storage } \\
\text { containers, with consequent low coverage rates. }\end{array}$ \\
\hline $\begin{array}{l}\text { Entomological } \\
\text { monitoring } \\
\text { and surveillance }\end{array}$ & $\begin{array}{l}\text { Monitoring of vector populations to target } \\
\text { Control in time and space and to provide feedback for } \\
\text { program adjustment }\end{array}$ & $\begin{array}{l}\text { Generating routine entomological surveillance data } \\
\text { that are not analyzed or utilized in a timely and } \\
\text { efficient manner for management decision-making. }\end{array}$ \\
\hline
\end{tabular}

\section{Table 5. Rational practices to treat dengue patient.}

\begin{tabular}{clll}
\hline & Good clinical practice & Bad clinical practice \\
\hline 1 & $\begin{array}{l}\text { Assessment and follow-up of patients with non-severe dengue } \\
\text { and careful instruction of warning signs to watch out for }\end{array}$ & $\begin{array}{l}\text { Sending patients with non-severe dengue home with no } \\
\text { follow-up and inadequate instructions }\end{array}$ \\
2 & $\begin{array}{l}\text { Administration of paracetamol for high fever if the patient is } \\
\text { uncomfortable }\end{array}$ & Administration of acetylsalicylic acid (aspirin) or ibuprofen \\
3 & Obtaining a hematocrit level before and after fluid boluses & $\begin{array}{l}\text { Not knowing when hematocrit levels are taken with respect to } \\
\text { fluid therapy }\end{array}$ \\
4 & $\begin{array}{l}\text { Clinical assessment of the hemodynamic status before and after } \\
\text { each fluid bolus }\end{array}$ & No clinical assessment of patient with respect to fluid therapy \\
5 & $\begin{array}{l}\text { Interpretation of hematocrit levels in the context of fluid } \\
\text { administered and hemodynamic assessment }\end{array}$ & $\begin{array}{l}\text { Interpretation of hematocrit levels independent of clinical } \\
\text { status }\end{array}$ \\
6 & $\begin{array}{l}\text { Administration of intravenous fluids for repeated vomiting or a } \\
\text { high or rapidly rising hematocrit }\end{array}$ & $\begin{array}{l}\text { Administration of intravenous fluids to any patient with } \\
\text { non-severe dengue }\end{array}$ \\
7 & $\begin{array}{l}\text { Use of isotonic intravenous fluids for severe dengue } \\
8\end{array}$ & $\begin{array}{l}\text { Giving intravenous fluid volume just sufficient to maintain effective } \\
\text { circulation during the period of plasma leakage for severe dengue }\end{array}$ & $\begin{array}{l}\text { Excessive or prolonged intravenous fluid administration for } \\
\text { severe dengue }\end{array}$ \\
9 & $\begin{array}{l}\text { Avoiding intramuscular injections in dengue patients } \\
\text { Giving intramuscular injections to dengue patients }\end{array}$ \\
11 & $\begin{array}{l}\text { Intravenous fluid rate and frequency of monitoring and hematocrit } \\
\text { measurement adjusted according to the patient's condition }\end{array}$ & $\begin{array}{l}\text { Fixed intravenous fluid rate and unchanged frequency of } \\
\text { monitoring and hematocrit measurement during entire } \\
\text { hospitalization for severe dengue }\end{array}$ \\
\hline
\end{tabular}


of dengue. But, the development of drugs and vaccines has the potential to revolutionize this. For an anti-dengue drug and vaccines, there are various requirements. Oral route of administration, frequency of dosing of once per day, stability in the face of heat and humidity, a long shelf-life, and small/reasonable cost of goods and ease of formulation to permit a reasonably priced product should be included in the minimal target drug profile [14]. The drug must be active against all serotypes, reduce symptoms, and reduce the incidence of severe disease, with respect to clinical efficacy. In addition, a safe and sound drug should be evaluated to make use of prophylactic as well as pediatrics after suitable trials.

\section{References}

[1] Westaway, E.G. and Blok, J. (1997) Taxonomy and Evolutionary Relationships of Flaviviruses. In: Dengue and Dengue Hemorrhagic Fever, CAB International, London, 147-173.

[2] Gubler, D.J. (1987) Dengue and Dengue Hemorrhagic Fever in the Americas. Puerto Rico Health Science Journal, 6, 107-111.

[3] Gubler, D.J. (1997) Dengue and Dengue Hemorrhagic Fever: Its History and Resurgence as a Global Public Health Problem. In: Gubler, D.J. and Kuno, G., Eds., Dengue and Dengue Hemorrhagic Fever, CAB International, London, $1-22$.

[4] Gubler, D.J. (2001) The Global Pandemic of Dengue/Dengue Hemorrhagic Fever: Current Status and Prospects for the Future. Annals, Academy of Medicine, Singapore.

[5] Gubler, D.J. and Trent, D.W. (1994) Emergence of Epidemic Dengue/Dengue Hemorrhagic Fever as a Public Health Problem in the Americas. Infectious Agents and Disease, 2, 383-393.

[6] Gubler, D.J. (1996) Arboviruses as Imported Disease Agents: The Need for Increased Awareness. Achieve Virology, 11, 21-32.

[7] Reiter, P. and Gubler, D.J. (1997) Surveillance and Control of Urban Dengue Vectors. Dengue and Dengue Hemorrhagic fever. United Kingdom: CAB International, London, 425-462.

[8] WHO (1997) Dengue Hemorrhagic Fever: Diagnosis, Treatment, Prevention and Control. 2nd Edition, World Health Organization, Geneva.

[9] Guha-Sapir, D. and Schimmer, B. (2005) Dengue Fever: New Paradigms for a Changing Epidemiology. Emerging Themes in Epidemiology, 2. http://dx.doi.org/10.1186/1742-7622-2-1

[10] Deen, J., et al. (2006) The WHO dengue Classification and Case Definitions: Time for a Reassessment. Lancet, 368, 170-173. http://dx.doi.org/10.1016/S0140-6736(06)69006-5

[11] Rigau-Perez, J. (2006) Severe Dengue: The Need for New Case Definitions. Lancet Infectious Diseases, 6, $297-302$. http://dx.doi.org/10.1016/S1473-3099(06)70465-0

[12] Bandyopadhyay, S., Lum, L.C. and Kroeger, A. (2006) Classifying Dengue: A Review of the Difficulties in Using the WHO Case Classification for Dengue Haemorrhagic Fever. Tropical Medicine and International Health, 11, 12381255. http://dx.doi.org/10.1111/j.1365-3156.2006.01678.x

[13] Rigau-Perez, J.G., et al. (1998) Dengue and Dengue Haemorrhagic Fever. Lancet, 352, 971-977. http://dx.doi.org/10.1016/S0140-6736(97)12483-7

[14] Keller, T.H., et al. (2006) Finding New Medicines for Flaviviral Targets. Novartis Foundation Symposium, 277, 102114. http://dx.doi.org/10.1002/0470058005.ch8 
Scientific Research Publishing (SCIRP) is one of the largest Open Access journal publishers. It is currently publishing more than 200 open access, online, peer-reviewed journals covering a wide range of academic disciplines. SCIRP serves the worldwide academic communities and contributes to the progress and application of science with its publication.

Other selected journals from SCIRP are listed as below. Submit your manuscript to us via either submit@scirp.org or Online Submission Portal.
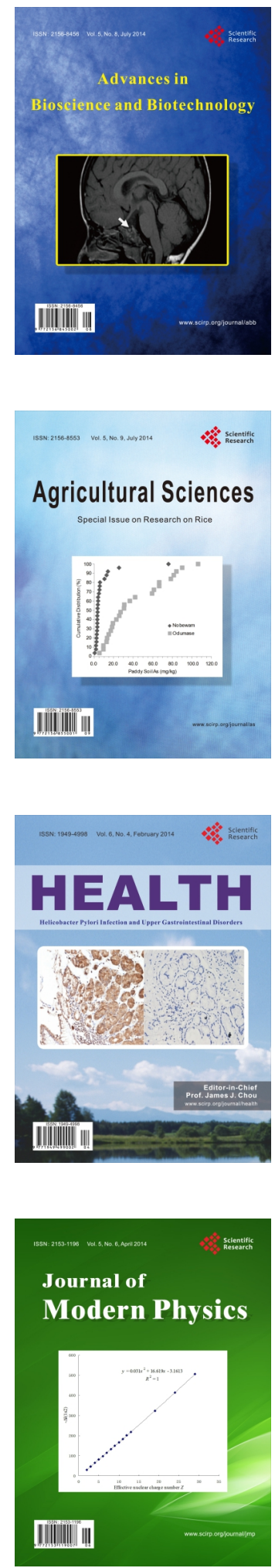
